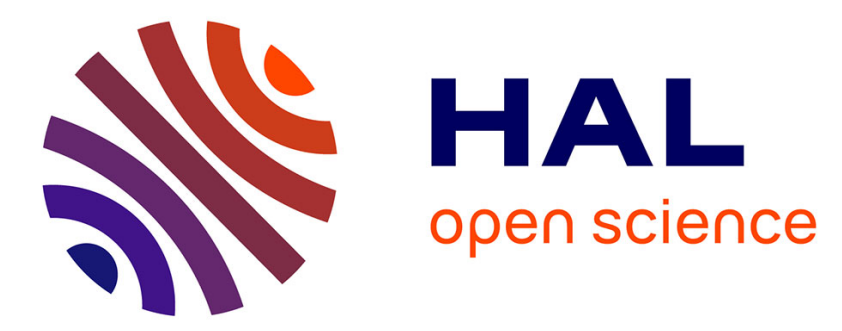

\title{
Control of the growth of electrodeposited zinc oxide on FTO glass
}

\author{
Hajar Ghannam, Cyrille Bazin, Adil Chahboun, Mireille Turmine
}

\section{To cite this version:}

Hajar Ghannam, Cyrille Bazin, Adil Chahboun, Mireille Turmine. Control of the growth of electrodeposited zinc oxide on FTO glass. CrystEngComm, 2018, 20 (41), pp.6618 - 6628. 10.1039/c8ce01223g . hal-01907494

\section{HAL Id: hal-01907494 \\ https://hal.sorbonne-universite.fr/hal-01907494}

Submitted on 29 Oct 2018

HAL is a multi-disciplinary open access archive for the deposit and dissemination of scientific research documents, whether they are published or not. The documents may come from teaching and research institutions in France or abroad, or from public or private research centers.
L'archive ouverte pluridisciplinaire HAL, est destinée au dépôt et à la diffusion de documents scientifiques de niveau recherche, publiés ou non, émanant des établissements d'enseignement et de recherche français ou étrangers, des laboratoires publics ou privés. 


\section{Control of the growth electrodeposited Zinc oxide onto FTO glass}

Received 00th January 20xx, Accepted 00th January 20xx

DOI: $10.1039 / \times 0 \times x 00000 x$

www.rsc.org/

\author{
Hajar Ghannam ${ }^{\mathrm{a}, \mathrm{b}}$, Cyrille Bazin ${ }^{\mathrm{a}}$, Adil Chahboun ${ }^{\mathrm{b}}$, Mireille Turmine*a
}

\begin{abstract}
In this work, zinc oxide ( $\mathrm{ZnO}$ ) was directly electrodeposited onto Fluorine-doped tin oxide (FTO). The physical and chemical heterogeneity of FTO have contributed to important and exploitable results. In fact, the doping of tin dioxide $\left(\mathrm{SnO}_{2}\right)$ with fluorine distorts its rutile crystal lattice. This distortion leads to contraction mechanical constraints on the network contributing to a rough surface morphology. Moreover, the nano-roughness of FTO surface impedes the epitaxial growth of $\mathrm{ZnO}$ nanorods. However, this roughness combined with the chemical heterogeneity of the FTO surface leads to favored growth sites. This can be explained by the presence of fluorine atoms, into the $\mathrm{SnO}_{2}$ network, with a stronger electronegativity which attracts the $\mathrm{ZnO}$ nuclei. The accumulation of many nuclei around the same electronegative spot contributes to the development of nanoflower-like structures or tilted nanorods. In such case, the non-polar facets of ZnO are exposed and the electrodeposited film is highly hydrophobic. The growth of $\mathrm{ZnO}$ onto FTO was studied by varying four main parameters of the synthesis: time of electrodeposition, temperature, concentration of $\mathrm{Zn}^{2+}$ precursor and concentration of $\mathrm{KCl}$. The influence of those parameters on the shape, size, growth mechanism, and density of the ZnO electrodeposit was discussed. Thus, when the concentration of $\mathrm{Zn}^{2+}$ precursor increases from 0.1 to $5 \mathrm{mM}$, the nanorods' size decreases but the density of these nanostructure increases leading to their organization in nanoflowers. However, the increase of $\mathrm{KCl}$ concentration from 0.5 to $4 \mathrm{M}$ causes a change of the $\mathrm{ZnO}$ nanostructures shape from hexagonal nanorod arrays to nanopencil arrays and also a significant decrease of density accompanied with a significant increase of $\mathrm{ZnO}$ nanostructures size whose diameter varies from 90 to $200 \mathrm{~nm}$. Furthermore, the time of electrodeposition is a key parameter influencing the height of $\mathrm{ZnO}$ nanorods. Finally, a good crystallization of $\mathrm{ZnO}$ is observed at high temperature (about $80^{\circ} \mathrm{C}$ ).
\end{abstract}

\section{Introduction}

Zinc oxide $(\mathrm{ZnO})$ is a low cost and non-toxic material. It has a large band gap ( $3.3 \mathrm{eV}$ ) absorbing UV rays hence its application as an anti-UV coating ${ }^{1}$. It is used, also, in the absorber layer for photovoltaic applications ${ }^{2}$. The structural property of $\mathrm{ZnO}$ thin films has a major influence on the observed change of its electrical, optical, photocatalytic and wettability properties. ${ }^{3-12}$ These properties can be improved or weakened according to the nanostructures size. In fact, when the nano-roughness of ZnO film decreases, conductivity and photocatalytic activity decrease, on the other hand the transmittance increases. ${ }^{13,14}$ Moreover, the nanostructures influence the wettability behavior of a surface, playing an amplifier role. A hydrophobic surface becomes super-hydrophobic when nano-roughness increases and vice versa. ${ }^{15}$ Therefore, the study of $\mathrm{ZnO}$ nanostructures is very important, since many properties depend on their shape and/or size. $\mathrm{ZnO}$ nanostructures can be grown in forms of nanoplates, nanoflowers, nanorods, nanotubes ${ }^{16}$, etc. $\mathrm{ZnO}$ nanorod is one of the more interesting form for photovoltaic application thanks to the large surface area. ${ }^{17}$ The geometric features of $\mathrm{ZnO}$ nanorods depend on synthesis technique and deposition condition. Electrochemical technique is the most efficient method for tuning structural properties. $^{18}$

Several studies were carried out in aim to control the growth

\footnotetext{
${ }^{a}$ Sorbonne Université, CNRS, Laboratoire Interfaces et Systèmes Electrochimiques (LISE), 75005 Paris, France

${ }^{b .}$ Abdelmalek Essaadi University, FST Tanger, laboratoire des Nanomatériaux et Couches Minces (NCM), 90000 Tangier, Morocco

*corresponding author: mireille.turmine@upmc.fr
}

of $\mathrm{ZnO}$ using electrochemical method by varying the concentration and nature of supporting electrolyte, or the concentration of the precursors $\left(\mathrm{Zn}^{2+}\right.$ and $\left.\mathrm{OH}^{-}\right)$. Skompska et al. ${ }^{19}$ have presented an extensive review about electrodeposition of $\mathrm{ZnO}$ nanorod arrays on transparent conducting substrates. Tena-Zaera et $a l^{20}$ have studied the effect of supporting electrolyte concentration (potassium chloride) on the $\mathrm{ZnO}$ nanostructure electrodeposited onto Fluorine-doped Tin Oxide (FTO) first covered by a seed layer of $\mathrm{ZnO}$ nanocrystallite. They showed that the increase of $\mathrm{KCl}$ concentration causes a rise of $\mathrm{ZnO}$ deposition efficiency. Furthermore, for a high concentration of $\mathrm{KCl}(>1 \mathrm{M})$ a lateral growth of $\mathrm{ZnO}$ is favored. Elias et al. ${ }^{21}$ have investigated the effect of the anion nature of the supporting electrolyte on the features of the $\mathrm{ZnO}$ nanostructures, showing that the change of anion nature leads to a difference in adsorption behavior onto $\mathrm{ZnO}$ nanostructures, causing a variation on $\mathrm{OH}$ production rate and therefore a modification of $\mathrm{ZnO}$ nanostructure sizes. In fact, several studies have been focused on the effect of the concentration of $\mathrm{Zn}^{2+}$ precursor on $\mathrm{ZnO}$ nanostructure growth, finding that the concentration of $\mathrm{Zn}^{2+}$ precursor is the major parameter influencing the $\mathrm{ZnO}$ geometric dimensions; the size of $\mathrm{ZnO}$ nanostructures increases when concentration of $\mathrm{Zn}^{2+}$ precursor rises. ${ }^{22}$ Other parameters, as time and temperature of the electrodeposition, were studied. $^{23,24}$

In this work, we have explored the effect of electrosynthesis parameters on the ZnO growth on FTO. Contrarily to the majority of the published studies, we made the choice to electrodeposit the $\mathrm{ZnO}$ thin layer directly on FTO surface in order to simplify the operating mode and to benefit from the surface nature of the FTO. Most often, only one characteristic 
is sought such as maximum of hydrophobicity ${ }^{25}$ and few studies have considered the variations of the experimental conditions on the morphology of $\mathrm{ZnO}$ nanostructures directly deposited on the FTO. Xu et al. ${ }^{26}$ have examined the effect of some additives in order to control the $\mathrm{ZnO}$ nanostructures growth and especially they sought the better conditions to obtain compact epitaxial growth of $\mathrm{ZnO}$ nanostructures. In our case, we provided four main parameters: the concentration of $\mathrm{Zn}^{2+}$ precursor, concentration of supporting electrolyte $\mathrm{KCl}$, time and temperature of electrodeposition. The variations of these key parameters modified the morphology of $\mathrm{ZnO}$ nanostructures and the growth mechanism.

\section{Experimental}

ZnO was successfully electrochemically deposited by using three-electrode classical cell. FTO glass (from Solems, $80 \mathrm{~nm}$ thickness), a saturated calomel electrode (SCE) and a Zinc rod was used as working electrode (WE), reference electrode (RE) and counter electrode (CE), respectively. FTO was cleaned prior any use with acetone and ethanol, for $10 \mathrm{~min}$ each, in an ultrasonic bath, afterwards it was rinsed with distilled water.

To deposit $\mathrm{ZnO}$, the three electrodes (CE, WE and RE) were vertically immersed in an aqueous electrolyte containing $\mathrm{ZnCl}_{2}$ (MERCK, purity>95\%) as a source of $\mathrm{Zn}^{2+}$, gaseous dioxygen $\left(\mathrm{O}_{2}\right)$ as $\mathrm{OH}^{-}$precursor and $\mathrm{KCl}$ (VWR International, purity 99.0$100.5 \%)$ was used as supporting electrolyte to increase the electrical conductivity of the solution. The temperature of the solution was kept constant using a cryostat bath.

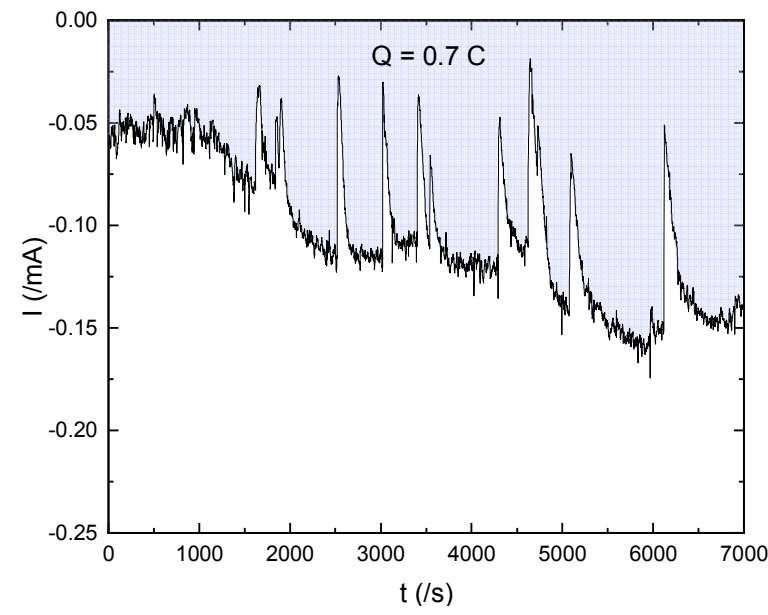

Fig. 1 The chronoamperograms for the preparation of $\mathrm{ZnO}$ nanostructure on FTO at $-1.0 \mathrm{~V} / \mathrm{SCE}$ during $7000 \mathrm{~s}$ in a $\mathrm{O}_{2}$ saturated aqueous medium of $2.5 \mathrm{mM} \mathrm{ZnCl}_{2}$ and $0.1 \mathrm{M}$ $\mathrm{KCl}$.

The electrodeposition of $\mathrm{ZnO}$ is generally realized by an elevation of the local $\mathrm{pH}$, due to the reduction of the oxygen in order to provide hydroxides around the surface. Then, the formation of metal oxide is made by chemical reaction between the native hydroxides $\left(\mathrm{OH}^{-}\right)$and the metal cations present in the solution, according to the following reactions under static-potential $(\mathrm{E}=-1 \mathrm{~V} / \mathrm{SCE})$ :

$$
\begin{aligned}
& \mathrm{O}_{2}+4 \mathrm{e}+2 \mathrm{H}_{2} \mathrm{O} \rightarrow 4 \mathrm{OH}^{-} \\
& \mathrm{Zn}^{2+}+2 \mathrm{OH}^{-} \rightarrow \mathrm{ZnO}+\mathrm{H}_{2} \mathrm{O}
\end{aligned}
$$

This can be summed up as

$$
\mathrm{Zn}^{2+}+1 / 2 \mathrm{O}_{2}+2 \mathrm{e} \rightarrow \mathrm{ZnO}
$$

The quantity of $\mathrm{ZnO}$ deposited on the cathode was estimated from the total electric charge, $Q$ (in Coulombs). The latter was calculated from the integration of the chronoamperometric curve (Fig. 1). From the Faraday's law, one can write

$$
m=\frac{Q \times M}{Z \times F} \quad \text { (eq.1) }
$$

In which, $m$ is the mass of ZnO electrodeposited on the WE (FTO), $F$ ( $=96500 \mathrm{C} \mathrm{mol}^{-1}$ ) is the Faraday constant, $z$ is the number of transferred electrons per ion which is equal to 2 , and $M$ is the molar mass of $\mathrm{ZnO}\left(81.38 \mathrm{~g} \mathrm{~mol}^{-1}\right)$.

The morphology of the electrosynthesized $\mathrm{ZnO}$ thin films was analyzed by field emission scanning electron microscope (SEMFEG) ULTRA 55 ZEISS. The crystal structure of $\mathrm{ZnO}$ thin films was investigated by Empyrean Panalytical X-ray diffraction (XRD).

\section{Results and discussion}

To study the ZnO growth on FTO substrate, four main parameters (concentration of Zinc precursor, of the supporting electrolyte $\mathrm{KCl}$, time and temperature of electrodeposition) were changed during the $\mathrm{ZnO}$ electrosynthesis.

\subsection{Effect of $\mathrm{ZnCl}_{2}$ concentration on $\mathrm{ZnO}$ nanorods growth onto FTO}

Several aqueous solutions containing the same $\mathrm{KCl}$ concentration $(0.1 \mathrm{M})$ but different concentrations of $\mathrm{ZnCl}_{2}$ (between 0.1 to $5 \mathrm{mM}$ ) were prepared. All these solutions were saturated with oxygen by bubbling. The electrodeposition of $\mathrm{ZnO}$ on FTO was performed at $80^{\circ} \mathrm{C}$ during 1000 s at $-1 \mathrm{~V} / \mathrm{SCE}$. The SEM pictures (Fig. 2) show that at low $\mathrm{ZnCl}_{2}$ concentration $(<0.5 \mathrm{mM})$, the nanorods of $\mathrm{ZnO}$ are gathered in 2-3 nanorods. For high concentrations of $\mathrm{ZnCl}_{2}$ (> $0.5 \mathrm{mM}$ ), the number of amassed nanorods increases leading to a nanoflower shape. Therefore, the density of nanocolumns increases when the concentration of $\mathrm{ZnCl}_{2}$ increases. For a concentration of $0.1 \mathrm{mM}$ the density is about 21 nanorods $/ \mu \mathrm{m}^{2}$ and for a concentration of $5 \mathrm{mM}$ the density is about 73 nanorods $/ \mu \mathrm{m}^{2}$. 


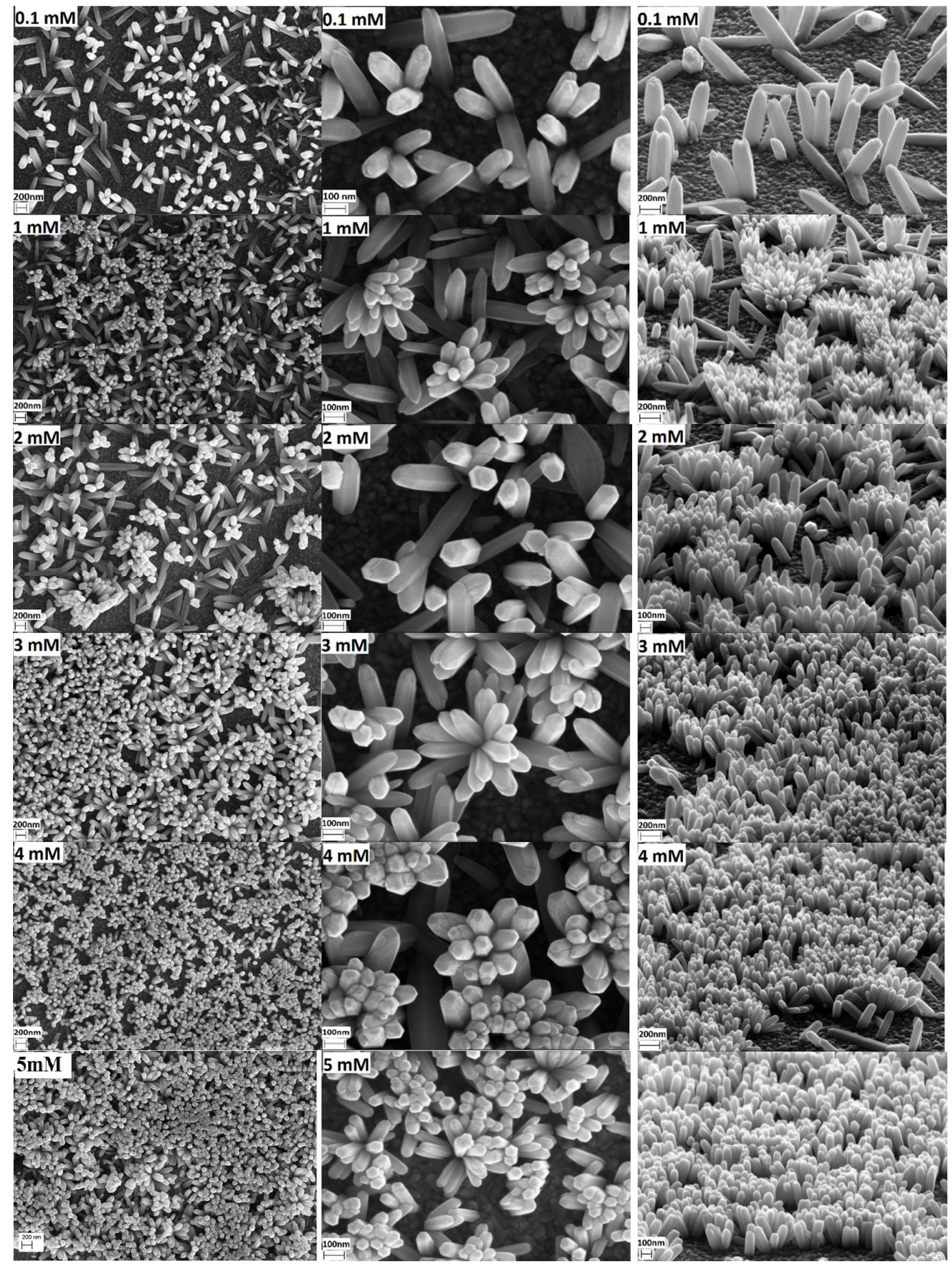

Fig. $2 \mathrm{SEM}$ images of $\mathrm{ZnO}$ nanorods (plan and cross-sectional views) obtained in different $\mathrm{ZnCl}$ concentrations, at $80^{\circ} \mathrm{C}$, during $1000 \mathrm{~s}$, at $\mathrm{E}=-1 \mathrm{~V} / \mathrm{SCE}$, in $0.1 \mathrm{M} \mathrm{KCl}$

The polarity of underlying surface plays a main role on the apparition regions of $\mathrm{ZnO}$ nanostructures, as illustrated by Lee et $a I^{27}$ and Perillat-Merceroz et $a .^{28}$ who generated a selective growth of $\mathrm{ZnO}$ by controlling the surface polarity. In our case, this underlying surface polarity can explain the observed $\mathrm{ZnO}$ growth. The difference in electronegativity between FTO atoms generates some more welcoming regions for $\mathrm{ZnO}$ deposition.
Hence, due to its polarity, the first nucleus of $\mathrm{ZnO}$ choose fluorine atom to be linked to the surface through its $\mathrm{Zn}$-polar facet. The number of nuclei linked to the surface depends on the zinc precursor concentration; a high concentration of $\mathrm{Zn}^{2+}$ precursor gives rise to a high density of $\mathrm{ZnO}$ nuclei around the same region contributing after growth process to nanoflower form (Fig. 3). 
Contrariwise the density, the height and width of $\mathrm{ZnO}$ nanorods decrease when the concentration of $\mathrm{ZnCl}_{2}$ increases. Thus, when the $\mathrm{ZnCl}_{2}$ concentration increases from 0.1 to $5 \mathrm{mM}$, we found a

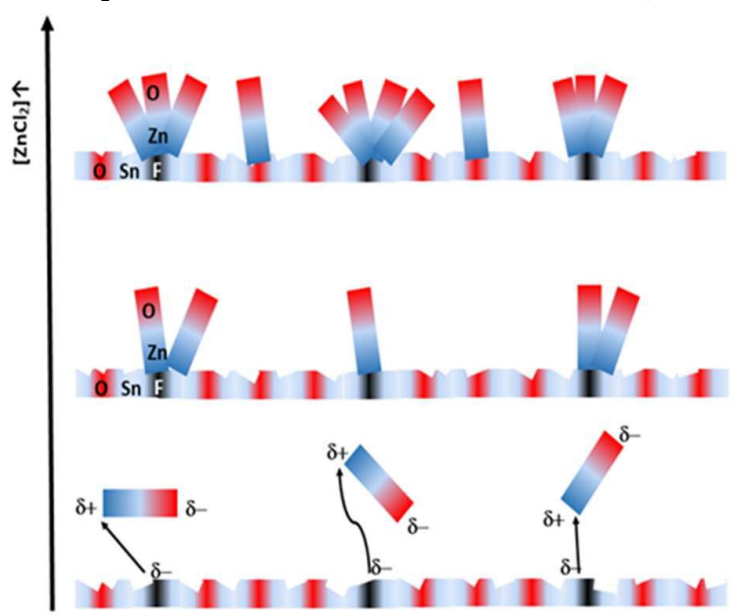

Fig. 3 Schematic illustration of $\mathrm{ZnO}$ growth mechanism for different concentrations of $\mathrm{ZnCl}_{2}$.

diminution in height and width (Fig. 4). This reduction in size of $\mathrm{ZnO}$ nanorods is accompanied by mass loss (Table 1 ). The mass of $\mathrm{ZnO}$ deposited on FTO increases when concentration of $\mathrm{ZnCl}_{2}$ varies from 0.1 to $1 \mathrm{mM}$ and decreases for concentration of $\mathrm{ZnCl}_{2}$ higher

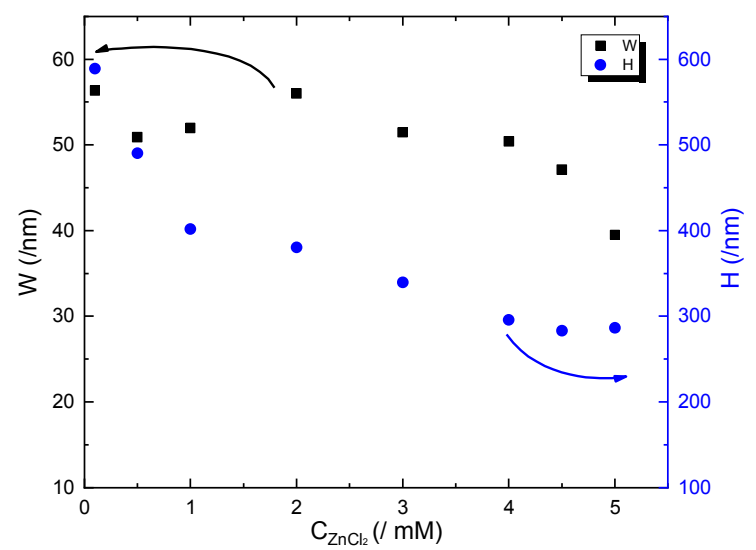

Fig. 4 Mean values of nanorod dimensions as a function of $\mathrm{ZnCl}_{2}$ concentration, black squares for the width $(W)$ and blue circles for the height $(H)$.

than $1 \mathrm{mM}$ (Table 1). This reduction of mass and size can be justified by the inequality between diffusion coefficient of molecular oxygen and $\mathrm{Zn}^{2+} .{ }^{29,30}$ The diffusion coefficient of molecular oxygen is more important than $\mathrm{Zn}^{2+}$ what makes the production of $\mathrm{OH}^{-}$ions faster than the transport of $\mathrm{Zn}^{2+}$. The $\mathrm{OH}^{-}$ions produced at the electrode diffuse towards the bulk solution through the $\mathrm{ZnO}$ nanostructures and adsorb on nanorod tips. The adsorption phenomenon of $\mathrm{OH}^{-}$ ions weakens the polarity of $\mathrm{ZnO}$ and therefore its growth. Moreover, we have to notice that our results are different from those presented by Elias et al. ${ }^{22}$ This is mainly related to the surface polarity. Elias et al. have studied the effect of concentration of $\mathrm{Zn}^{2+}$ precursor on $\mathrm{ZnO}$ growth on FTO first covered by a buffer layer of $\mathrm{ZnO}$ finding that the size of $\mathrm{ZnO}$ nanorods increases with the concentration of $\mathrm{Zn}^{2+}$ precursor in the solution. The coating of FTO surface by smooth $\mathrm{ZnO}$ layer before depositing the $\mathrm{ZnO}$ nanorods leads to a surface polarity equilibrium forming a homogeneous and well-dispersed deposit of $\mathrm{ZnO}$ nanorods.

\begin{tabular}{ccc}
\hline$\left[\mathrm{ZnCl}_{2}\right] /(\mathrm{mM})$ & Charge density $\left(/ \mathrm{C} \mathrm{cm}^{-2}\right)$ & $\mathrm{m}(\mathrm{ZnO})(/ \mu \mathrm{g})$ \\
\hline 0.1 & 0.136 & 57 \\
0.5 & 0.197 & 83 \\
1 & 0.199 & 84 \\
2 & 0.165 & 70 \\
3 & 0.160 & 67 \\
4 & 0.150 & 63 \\
5 & 0.145 & 61 \\
\hline
\end{tabular}

Table 1 Estimated values of mass for electrodeposited $\mathrm{ZnO}$ nanorods according to the concentration of zinc precursor.

\subsection{Time effect on ZnO nanorods growth on FTO}

Several $\mathrm{ZnO}$ samples were prepared from solution of $0.1 \mathrm{M} \mathrm{KCl}$ and $2.5 \mathrm{mM} \mathrm{ZnCl} 2$ saturated with oxygen by bubbling. The electrodeposition of $\mathrm{ZnO}$ is realized at $80^{\circ} \mathrm{C}$, constant potential $(-1 \mathrm{~V} / \mathrm{SCE})$ and for an electrodeposition time varying between 0 and 10000 s.

Fig. 5 depicts some SEM images of different ZnO growths on FTO surface as a function of the electrodeposition time. The dimension values of $\mathrm{ZnO}$ nanorods estimated from SEM images are gathered in Fig. 6. As shown on Fig. 5, the density of $\mathrm{ZnO}$ nanorods increases until time of 2000s. While, the density remains almost constant $\left(\approx 20\right.$ nanorods $\left./ \mu \mathrm{m}^{2}\right)$ for a deposition time higher than 2000s. If we focused on the nanostructures size, we can notice that the width increases in the first moment and then remains constant (around of 78nm) from an electrodeposition time of 3000s. Regarding the height variation of $\mathrm{ZnO}$ nanorods, a monotonous increase over the time was observed, it goes from $300 \mathrm{~nm}$ for $500 \mathrm{~s}$ to $1100 \mathrm{~nm}$ for 10000s. Moreover, as seen on Table 2, the mass of electrodeposited ZnO on FTO increases as a function of time.

\begin{tabular}{ccc}
\hline Time $(/ \mathrm{s})$ & Charge density $\left(/ \mathrm{C} \mathrm{cm}^{-2}\right)$ & $\mathrm{m}(\mathrm{ZnO})(/ \mu \mathrm{g})$ \\
\hline 500 & 0.048 & 20 \\
1000 & 0.1447 & 61 \\
2000 & 0.181 & 76 \\
3000 & 0.273 & 115 \\
4000 & 0.379 & 160 \\
5000 & 0.479 & 202 \\
6000 & 0.600 & 253 \\
7000 & 0.700 & 295 \\
8000 & 0.825 & 348 \\
9000 & 0.943 & 398 \\
10000 & 1.070 & 451 \\
\hline
\end{tabular}

Table 2 Estimated values of mass of electrodeposited $\mathrm{ZnO}$ nanorods as a function of time

The growth of $\mathrm{ZnO}$ on the rough FTO surface probably begins by the appearance of nuclei of $\mathrm{ZnO}$ on the anfractuosities due to the surface roughness. Those first nuclei adopt the same inclination angle than FTO nano-roughness hence the appearance of inclined nanorods of $\mathrm{ZnO}$. Ichinose et al. ${ }^{31}$ had discussed the influence of surface roughness on the $\mathrm{ZnO}$ orientation. Moreover, $\mathrm{ZnO}$ growth along $c$ axis is mainly related to its crystal structure. The Wurtzite crystal structure 
of $\mathrm{ZnO}$ is non-centrosymmetric. The absence of symmetry lattice along the $c$ axis which causes an instability of $\mathrm{ZnO} O$ center leads creating a dipole moment in the ZnO crystal polar facet (0001).

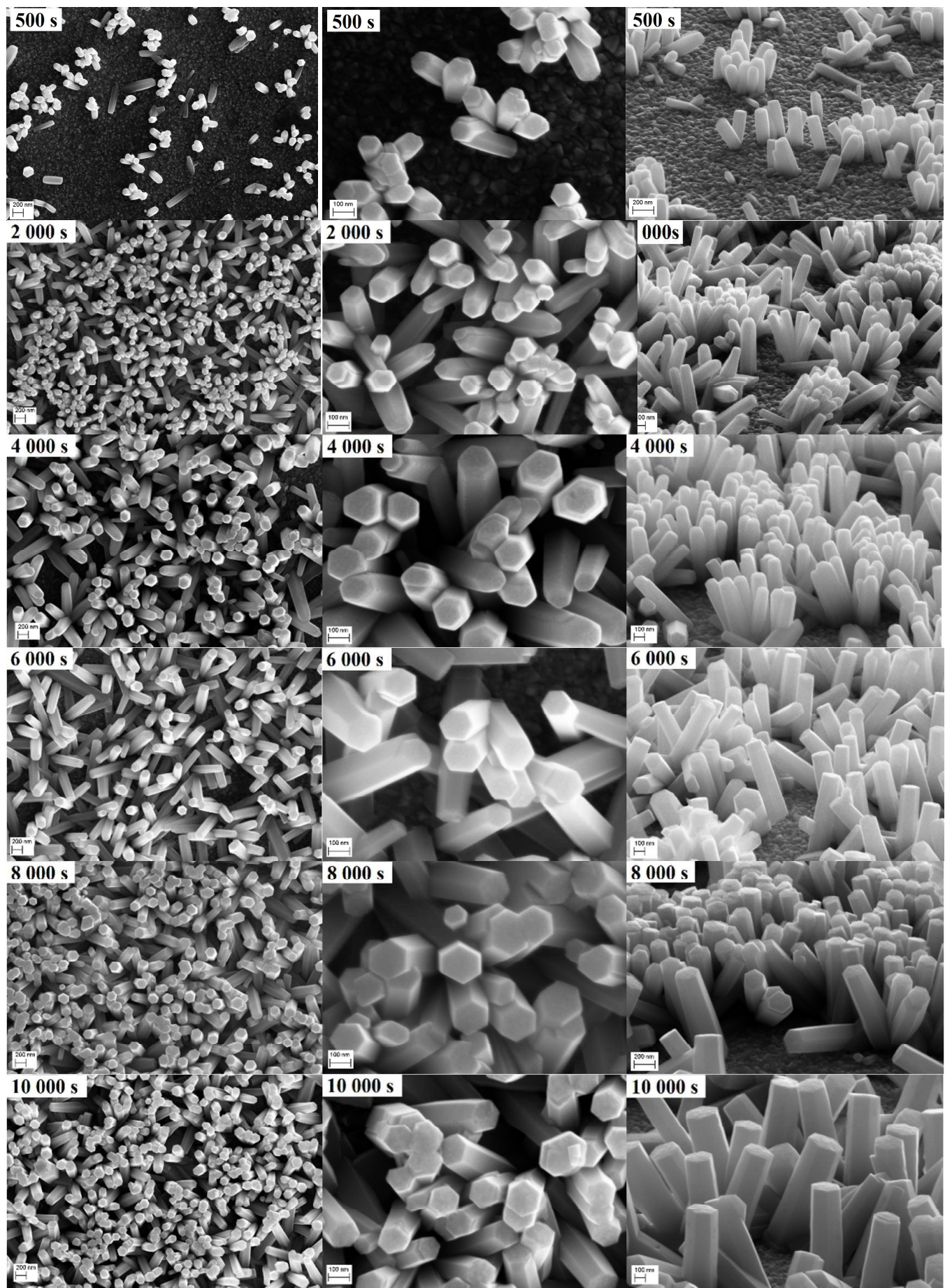

Fig. $5 \mathrm{SEM}$ images of $\mathrm{ZnO}$ nanorods (plan and cross-sectional views) for different electrodeposition times, at $80^{\circ} \mathrm{C},\left[\mathrm{ZnCl}_{2}\right]=2.5 \mathrm{mM},[\mathrm{KCl}]=0.1 \mathrm{M}$ and $\mathrm{E}=-1 \mathrm{~V} / \mathrm{SCE}$ 
The stability of the structure is then enhanced by binding the latter with the $\mathrm{Zn}$-polar plane $(000 \overline{1})$ of new $\mathrm{ZnO}$ mesh. As a function of time, stability / instability process of $\mathrm{ZnO}$ polar facets contributes to a repetition of $\mathrm{ZnO}$ bonding along $c$ axis at the atomic-scale leading to long nanorods at nanoscale (Fig. 7). The growth rate of $\mathrm{ZnO}$ is

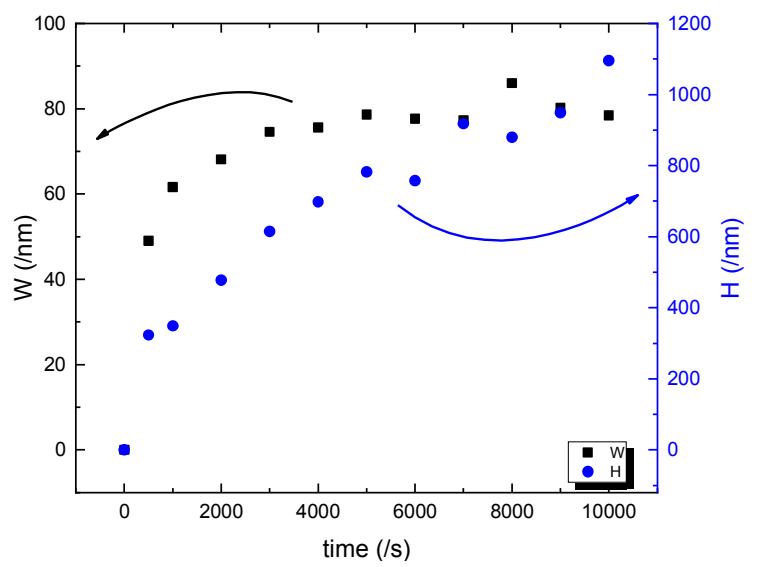

Fig. 6 Mean values of nanorod dimensions as a function of time, black squares for the width (W) and blue circles for the height $(\mathrm{H})$.

mainly related to the plane polarity of growth direction. In fact, the deposition speed of $\mathrm{ZnO}$ oriented along $\mathrm{Zn}$-polar plane is 1.5 times higher than $\mathrm{ZnO}$ oriented along O-polar plane. ${ }^{32-35}$ The growth rate of $\mathrm{ZnO}$ in our case is relatively slow due to the O-polar plane (0001) which is responsible for growth along $c$ axis.

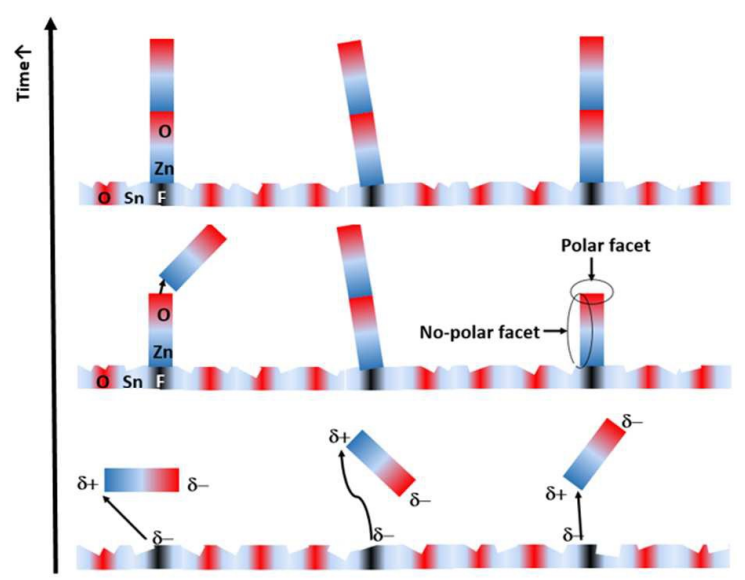

Fig. 7 Schematic illustration of $\mathrm{ZnO}$ growth mechanism for different synthesis times.

\subsection{Effect of $\mathrm{KCl}$ concentration on $\mathrm{ZnO}$ nanorods growth on FTO}

The effect of $\mathrm{KCl}$ concentration was carried out at constant temperature $\left(80^{\circ} \mathrm{C}\right)$, time $(1000 \mathrm{~s})$ and potential $(-1 \mathrm{~V} / \mathrm{SCE})$ of electrodeposition. The concentration of $\mathrm{Zn}^{2+}$ precursor is kept constant for all samples $(2.5 \mathrm{mM})$ and the $\mathrm{KCl}$ concentration varied from 0.1 to $0.5 \mathrm{M}$ in the electrolyte solution saturated with oxygen. SEM images (Fig. 8) and estimated mass results (Table 3) show that the concentration of the electrolyte support, $\mathrm{KCl}$, plays an inhibitor role on the $\mathrm{ZnO}$ electrodeposition when present in excess in the solution. The mass of $\mathrm{ZnO}$ electrodeposited on FTO and the density of $\mathrm{ZnO}$ nanorods decrease for a concentration of $\mathrm{KCl}$ higher than $0.5 \mathrm{M}$.

\begin{tabular}{ccc}
\hline$[\mathrm{KCl}](/ \mathrm{M})$ & Charge density $\left(/ \mathrm{C} \mathrm{cm}^{-2}\right)$ & $\mathrm{m}(\mathrm{ZnO})(/ \mu \mathrm{g})$ \\
\hline 0.1 & 0.144 & 61 \\
0.5 & 0.154 & 65 \\
1 & 0.138 & 58 \\
2 & 0.130 & 55 \\
3 & 0.126 & 53 \\
4 & 0.097 & 41 \\
\hline
\end{tabular}

Table 3 Estimated values of mass for $\mathrm{ZnO}$ nanorods electrodeposited for different support electrolyte concentrations.

Besides, the size of $\mathrm{ZnO}$ nanorods shows a significant growth at the level of the width and the height keeping the preferential direction of the growth according to $c$ axis (Fig. 9).

On the one hand, the presence of $\mathrm{KCl}$ excess prevents $\mathrm{ZnO}$ nuclei from binding to the surface. This excess contributes to adsorption of $\mathrm{K}^{+}$and $\mathrm{Cl}^{-}$ions on the surface forming a barrier which impedes $\mathrm{ZnO}$ from depositing and weakens the polarity of the surface. Also, the adsorption of $\mathrm{Cl}^{-}$and $\mathrm{K}^{+}$on the surface causes a decrease of $\mathrm{OH}^{-}$ around the surface contributing to a decrease of $\mathrm{ZnO}$ deposition rate. However, the first $\mathrm{ZnO}$ nuclei which appear near the surface bind to it and form a very attractive center for ZnO deposit (Fig. 10). Effect of $\mathrm{KCl}$ concentration on $\mathrm{ZnO}$ growth on FTO covered by nanocrystalline $\mathrm{ZnO}$ buffer layer has been reported by Tena-Zaera et $a .^{20}$ finding that the increase of $\mathrm{KCl}$ concentration mainly enhanced the longitudinal and lateral growth for a concentration of $\mathrm{KCl}$ higher than $1 \mathrm{M}$. This result is also observed in our case. TenaZaera et al. $^{20}$ found also that an increase of $\mathrm{KCl}$ concentration causes an increase of $\mathrm{ZnO}$ deposition efficiency. This result is observed for a concentration lower than 0.5M. But high concentrations of $\mathrm{KCl}(>0.5 \mathrm{M})$ cause a decrease of $\mathrm{ZnO}$ deposition efficiency.

Structurally, two main forms of $\mathrm{ZnO}$ nanorods can be distinguished according to the $\mathrm{KCl}$ concentration. The first one is $\mathrm{ZnO}$ nanorod arrays observed for a $\mathrm{KCl}$ concentration lower than $0.5 \mathrm{M}$. For this form, $\mathrm{ZnO}$ nanorods retain the hexagonal form of $\mathrm{ZnO}$ with a flat end. The second one is $\mathrm{ZnO}$ nanopencil arrays observed for a $\mathrm{KCl}$ concentration higher than $0.5 \mathrm{M}$. This form is generated by adsorption of $\mathrm{K}^{+}$ions on the O-polar plane of $\mathrm{ZnO}$ which weakens the 


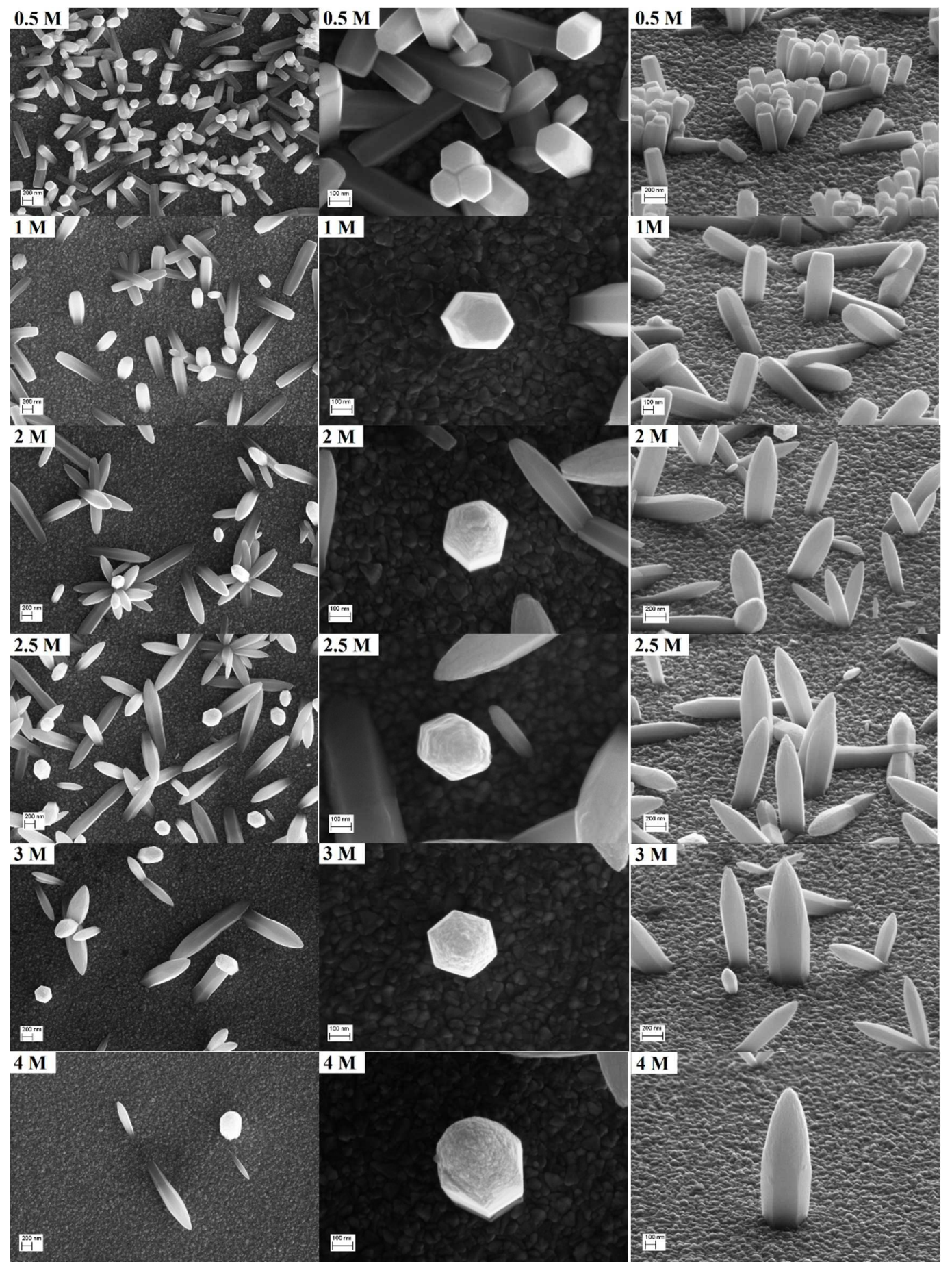

Fig. $8 \mathrm{SEM}$ images of $\mathrm{ZnO}$ nanorods (plan and cross-sectional view) for different $\mathrm{KCl}$ concentrations. $\mathrm{T}=80^{\circ} \mathrm{C},[\mathrm{ZnCl}]=2.5 \mathrm{mM}$, time $=1000 \mathrm{~s}$ and $\mathrm{E}=-1 \mathrm{~V} / \mathrm{SCE}$. 


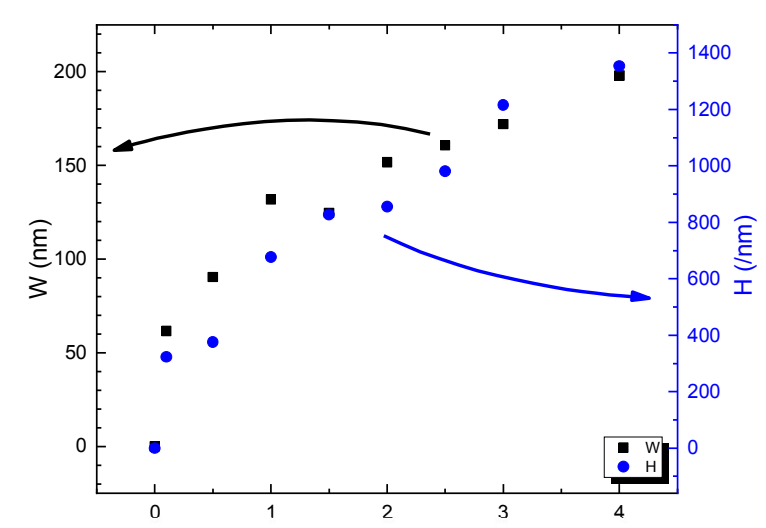

Fig. 9 Mean values of nanorod dimensions as a function of $\mathrm{KCl}$ concentration, black square for the width (W) and blue circles for the height $(H)$.

polarity of the plane (001) and prevents the natural growth of $\mathrm{ZnO}$. The adsorption effect is more important on the edges than on the

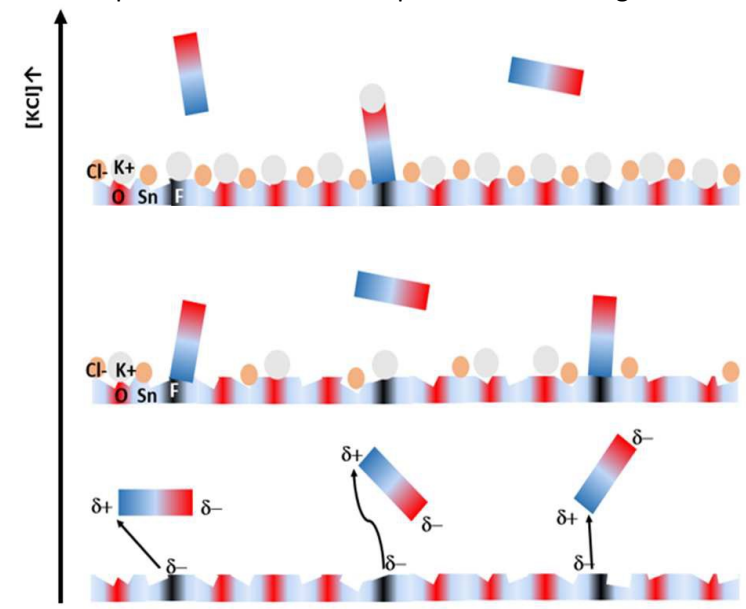

Fig. 10 Schematic illustration of $\mathrm{ZnO}$ growth mechanism for different concentrations of $\mathrm{KCl}$.

center of $\mathrm{ZnO}$ nanorods. $\mathrm{Xu}$ et $a .^{26}$ reported the effect of the adsorption of compounds other than $\mathrm{KCl}$ on the apparition of nanopencil arrays of $\mathrm{ZnO}$.

\subsection{Temperature effect on ZnO nanorods growth on FTO}

From the same electrolyte solution saturated with oxygen made of $\mathrm{ZnCl}_{2}(2.5 \mathrm{mM})$ and $\mathrm{KCl}(0.1 \mathrm{M})$, a series of sample was synthetized at the same potential (-1V/ SCE) and time (1000s) of electrodeposition but at various temperatures in the range of 30 to $80^{\circ} \mathrm{C}$.

The temperature plays an important role on the $\mathrm{ZnO}$ formation. A precipitation of zinc hydroxide is promoted after oxygen reduction. The zinc hydroxide is thermodynamically unstable, a high temperature promotes their dehydration and therefore the $\mathrm{ZnO}$ formation.

The mass of ZnO electrodeposited on FTO surface increases with the temperature (Table 4). The rise in temperature leads also to an increase of ion mobility which promotes the $\mathrm{ZnO}$ deposition.

\begin{tabular}{ccc}
\hline $\mathrm{T}\left(/{ }^{\circ} \mathrm{C}\right)$ & Charge density $\left(/ \mathrm{C} \mathrm{cm}^{-2}\right)$ & $\mathrm{m}(\mathrm{ZnO})(/ \mu \mathrm{g})$ \\
\hline 30 & 0.032 & 13 \\
40 & 0.106 & 45 \\
50 & 0.137 & 58 \\
60 & 0.138 & 58 \\
70 & 0.181 & 76 \\
80 & 0.204 & 86 \\
\hline
\end{tabular}

Table 4 Estimated values of mass for $\mathrm{ZnO}$ nanorods electrodeposited at various temperatures

The SEM images (Fig. 11) show the temperature effect on $\mathrm{ZnO}$ growth on FTO. As a function of temperature, the thin film of $\mathrm{ZnO}$ changes its appearance from a smooth thin film to nanostructure thin film, through randomly structures. For temperatures between 40 to $50^{\circ} \mathrm{C}, \mathrm{ZnO}$ growths on the surface as small grains having a rough wall. For temperature between 50 to $70^{\circ} \mathrm{C}, \mathrm{ZnO}$ nanorods begin to appear, but with a rough wall. For temperature equal to $80^{\circ} \mathrm{C}$, the hexagonal nanorods of $\mathrm{ZnO}$ grows with smooth walls and marked crystalline plans.

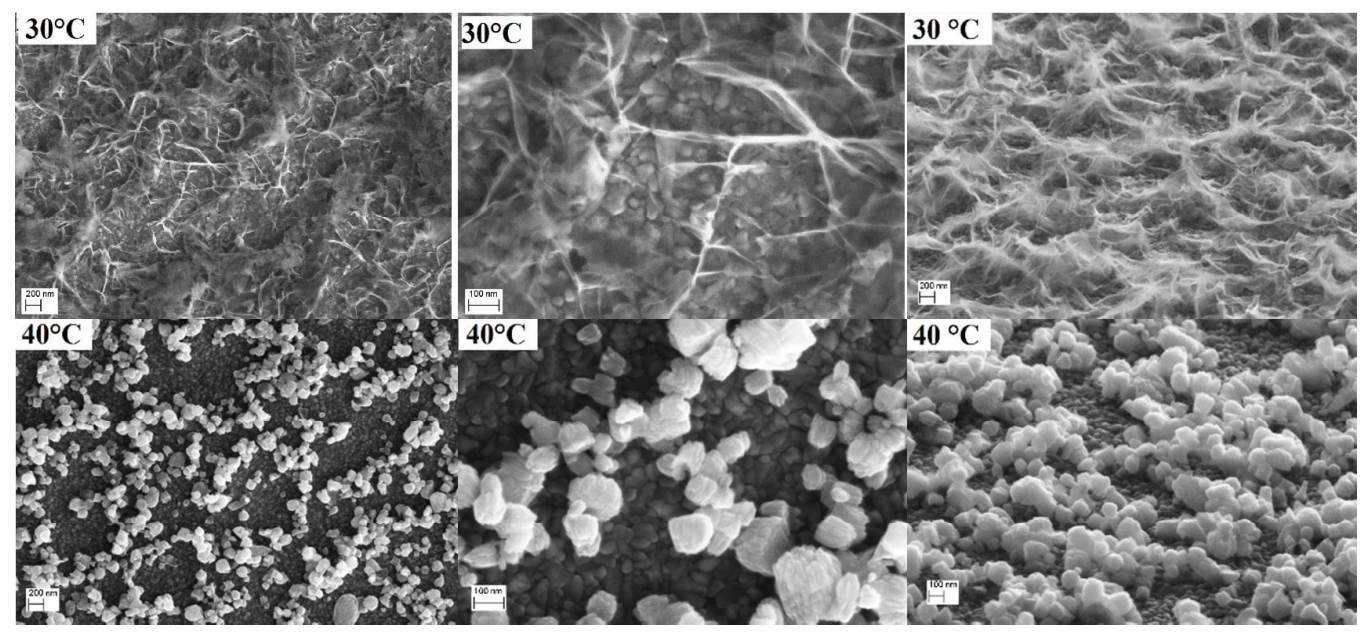




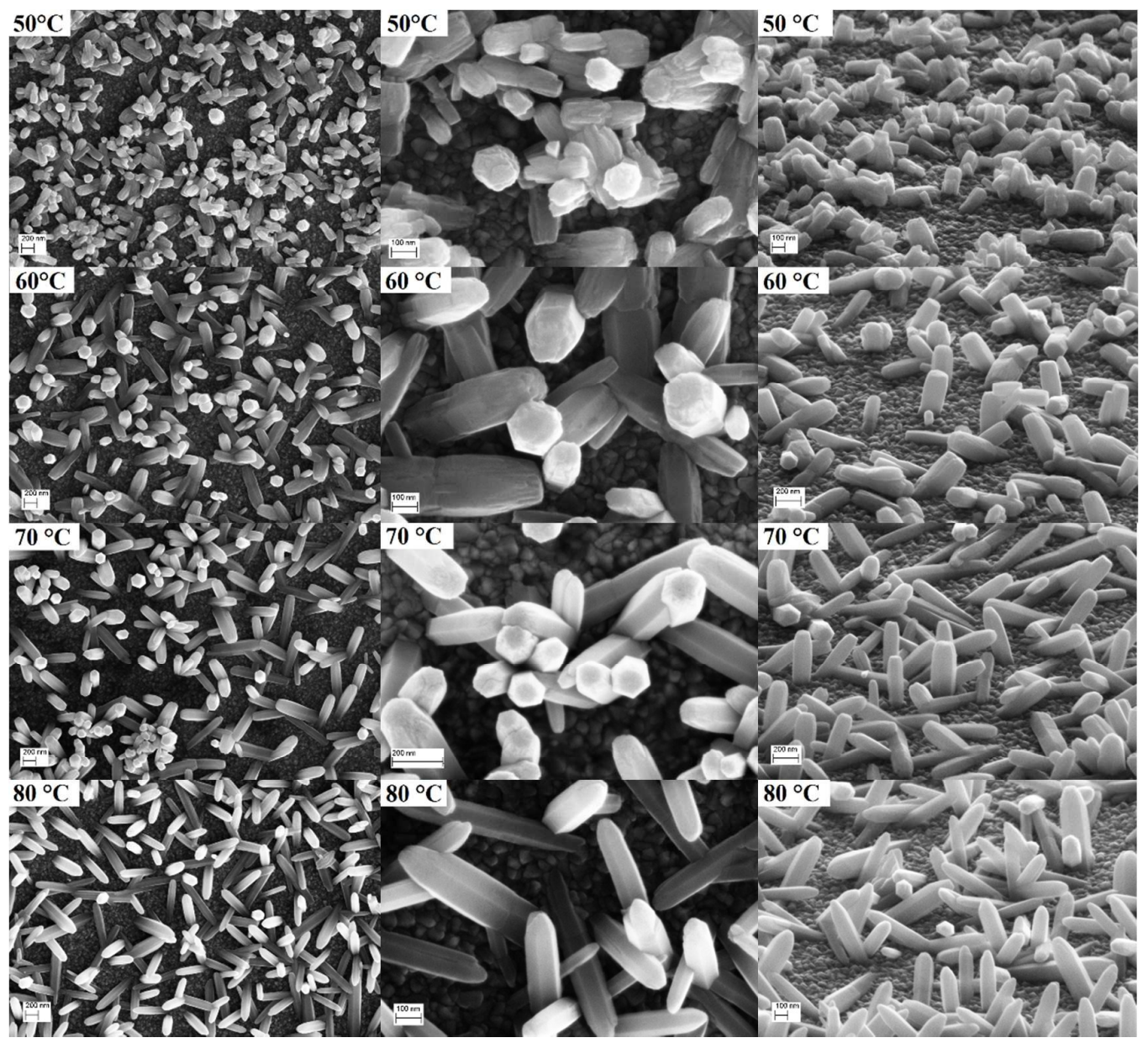

Fig. $11 \mathrm{SEM}$ images of $\mathrm{ZnO}$ nanorods (plan and cross-sectional view) for different temperatures. Time=1000s, $[\mathrm{ZnCl}]=2.5 \mathrm{mM},[\mathrm{KCl}]=0.1 \mathrm{M}$ and $\mathrm{E}=-1 \mathrm{~V} / \mathrm{SCE}$.

The XRD patterns results of $\mathrm{ZnO}$ nanostructured thin films showed that only at $80^{\circ} \mathrm{C}, \mathrm{ZnO}$ was crystallized under Wurtzite crystal structure. The Wurtzite crystal structure is identified by (100), (002),

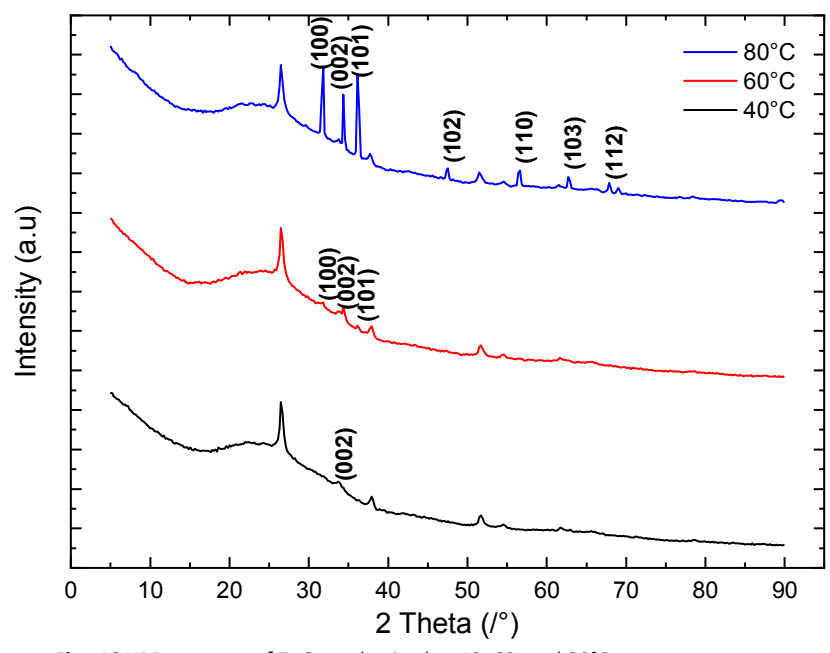

Fig. $12 \mathrm{XRD}$ patterns of $\mathrm{ZnO}$ synthesized at 40,60 , and $80^{\circ} \mathrm{C}$

(101), (102), (110), (103), (200) and (112) crystal planes locating at $2 \theta$ values of $31.8^{\circ}, 34.4^{\circ}, 36.3^{\circ}, 47.5^{\circ}, 56.6^{\circ}, 62.9^{\circ}, 66.4^{\circ}$, and $68.0^{\circ}$, respectively.

Moreover, the peaks at $2 \theta$ values of $27^{\circ}$ and $52^{\circ}$ correspond to FTO crystal structure (Fig. 12). These results agreed with several works which have studied the temperature effect on crystallization of material $^{23,24}$ finding that high temperatures give rise to a good crystallization of the material. Moreover, in our case, we can notice that the intensities of (100) and (101) planes are higher than this of (002). This is related to the surface roughness and especially to the inclination of $\mathrm{ZnO}$ nanorods revealing the most hydrophobic planes as mentioned by Chang et al. ${ }^{36}$

\section{Conclusion}

The electrodeposition in one step of $\mathrm{ZnO}$ nanorods on FTO is carried out under different conditions. The effect of four main parameters (concentration of $\mathrm{Zn}^{2+}$ precursor, time of electrodeposition, concentration of supporting electrolyte and temperature of electrodeposition) on the $\mathrm{ZnO}$ growth is studied. The concentration of $\mathrm{Zn}^{2+}$ precursor mainly plays a role on the density of nanorods. $\mathrm{A}$ high concentration of $\mathrm{Zn}^{2+}$ precursor causes a high nucleation rate around the fluorine atoms of the surface leading to nanoflower-like structures after growth process (Fig. 13 (a)). The electrodeposition 
time of ZnO mainly influences the height of nanorods (Fig. 13 (b)). Moreover, the temperature is an important parameter regarding the transfer of matter in the electrolyte and the appearance of $\mathrm{ZnO}$ nanorods with accented crystalline planes (Fig. 13 (c)). Finally, the concentration of $\mathrm{KCl}$ influences the nanorods density. A high concentration gives rise to a low density of nanorods. However, a high temperature increases the conductivity of the solution and promotes the dehydration of zinc hydroxide guaranteeing the
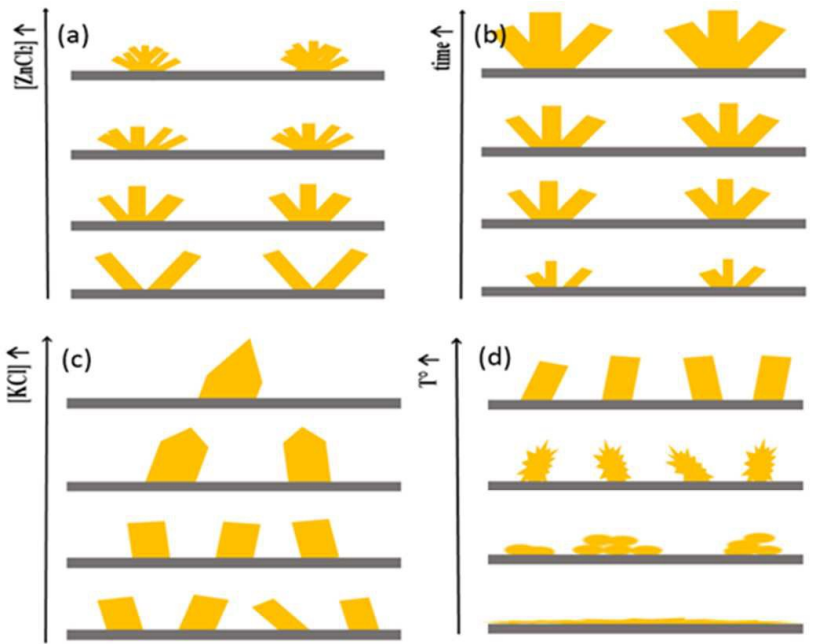

Fig. 13 Schematic view of $\mathrm{ZnO}$ growth on FTO under different conditions; (a) $\mathrm{ZnCl}_{2}$ concentration, (b) time, (c) $\mathrm{KCl}$ concentration and (d) temperature.

electrochemical deposition of ZnO (Fig. 13 (d)).

\section{Conficts of interest}

There are no conflicts to declare.

\section{Acknowledgements}

The authors thank the support of the Erasmus+ programme of the European Union, especially for the funding of H.G.

\section{References}

1 M. Sasani Ghamsari, S. Alamdari, W. Han and H.-H. Park, Int. J. Nanomedicine, 2017, Volume 12, 207-216.

2 R. Pietruszka, B. S. Witkowski, S. Gieraltowska, P. Caban, L. Wachnicki, E. Zielony, K. Gwozdz, P. Bieganski, E. Placzek-Popko and M. Godlewski, Sol. Energy Mater. Sol. Cells, 2015, 143, 99-104.

3 D. N. Papadimitriou, Thin Solid Films, 2016, 605, 215-231.

4 A. Henni, A. Merrouche, L. Telli, A. Karar, F. I. Ezema and H. Haffar, J. Solid State Electrochem., 2016, 20, 21352142.

5 A. Tello, H. Gomez, E. Munoz, G. Riveros, C. J. Pereyra, E. A. Dalchiele and R. E. Marotti, J. Electrochem. Soc., 2012, 159, D750-D755.
C. Badre, T. Pauporte, M. Turmine and D. Lincot, Nanotechnology, 2007, 18, 4.

J. Kennedy, P. P. Murmu, J. Leveneur, V. M. Williams, R. L. Moody, T. Maity and S. V. Chong, J. Nanosci. Nanotechnol., 2018, 18, 1384-1387.

K. Kaviyarasu, C. Maria Magdalane, K. Kanimozhi, J. Kennedy, B. Siddhardha, E. Subba Reddy, N. K. Rotte, C. S. Sharma, F. T. Thema, D. Letsholathebe, G. T. Mola and M. Maaza, J. Photochem. Photobiol. B, 2017, 173, 466-475.

J. Kennedy, F. Fang, J. Futter, J. Leveneur, P. P. Murmu, G. N. Panin, T. W. Kang and E. Manikandan, Diamond Relat. Mater., 2017, 71, 79-84.

J. Kennedy, P. P. Murmu, J. Leveneur, A. Markwitz and J. Futter, Appl. Surf. Sci., 2016, 367, 52-58.

J. Kennedy, P. P. Murmu, E. Manikandan and S. Y. Lee, Journal of Alloys and Compounds, 2014, 616, 614-617.

J. Kennedy, A. Markwitz, Z. Li, W. Gao, C. Kendrick, S. M. Durbin and R. Reeves, Current Applied Physics, 2006, 6, 495-498.

A. R. Khataee, A. Karimi, R. D. C. Soltani, M. Safarpour, Y. Hanifehpour and S. W. Joo, Applied Catalysis A: General, 2014, 488, 160-170.

K. C. Sekhar, A. Khodorov, A. Chahboun, S. Levichev, A. Almeida, J. A. Moreira, K. Kamakshi, C. J. R. Silva, M. Pereira and M. J. M. Gomes, Mater. Chem. Phys., 2012, 135, 174-180.

H. Ghannam, Z. O. El Hmaidi, Z. Y. Alami, M. Addou, A. Chahboun, M. Salem and M. Gaidi, International Renewable and Sustainable Energy Conference (IRSEC), Ouarzazate, MOROCCO, 2014.

N. Kıcır, T. Tüken, O. Erken, C. Gumus and Y. Ufuktepe, Appl. Surf. Sci., 2016, 377, 191-199.

H. Zhang, S. Jin, G. Duan, J. Wang and W. Cai, J. Mater. Sci. Technol., 2014, 30, 1118-1123.

G. Nagaraju, Y. H. Ko and J. S. Yu, Mater. Chem. Phys., 2015, 149-150, 393-399.

M. Skompska and K. Zarębska, Electrochim. Acta, 2014 127, 467-488.

R. Tena-Zaera, J. Elias, G. Wang and C. Levy-Clement, J. Phys. Chem. C, 2007, 111, 16706-16711.

J. Elias, R. Tena-Zaera and C. Levy-Clement, J. Phys. Chem. C, 2008, 112, 5736-5741.

J. Elias, R. Tena-Zaera and C. Lévy-Clément, J. Electroanal. Chem., 2008, 621, 171-177.

D. Pradhan and K. T. Leung, J. Phys. Chem. C, 2008, 112, 1357-1364.

A. Goux, T. Pauporté, J. Chivot and D. Lincot, Electrochim. Acta, 2005, 50, 2239-2248.

C. Badre, P. Dubot, D. Lincot, T. Pauporte and M. Turmine, J. Colloid Interface Sci., 2007, 316, 233-237.

L. F. Xu, Y. Guo, Q. Liao, J. P. Zhang and D. S. Xu, J. Phys. Chem. B, 2005, 109, 13519-13522.

S. H. Lee, T. Minegishi, J. S. Park, S. H. Park, J. S. Ha, H. J. Lee, H. J. Lee, S. Ahn, J. Kim, H. Jeon and T. Yao, Nano Lett., 2008, 8, 2419-2422.

G. Perillat-Merceroz, P. H. Jouneau, G. Feuillet, R. Thierry, M. Rosina and P. Ferret, Journal of Physics: Conference Series, 2010, 209, 012034.

A. Goux, T. Pauporté and D. Lincot, Electrochim. Acta, 2006, 51, 3168-3172.

B. B. Li, U. Philipose, C. F. de Souza and H. E. Ruda, J. Electrochem. Soc., 2011, 158, D282. 
31 K. Ichinose, T. Mizuno, M. Schuette White and T. Yoshida, J. Electrochem. Soc., 2014, 161, D195-D201.

32 X. Wang, Y. Tomita, O.-H. Roh, M. Ohsugi, S.-B. Che, Y. Ishitani and A. Yoshikawa, Appl. Phys. Lett., 2005, 86, 011921.

33 H. Kato, M. Sano, K. Miyamoto and T. Yao, J. Cryst. Growth, 2005, 275, e2459-e2465.

34 J. S. Park, J. H. Chang, T. Minegishi, H. J. Lee, S. H. Park, I. H. Im, T. Hanada, S. K. Hong, M. W. Cho and T. Yao, J. Electron. Mater., 2007, 37, 736-742.

35 J. S. Park, T. Minegishi, J. W. Lee, S. K. Hong, J. H. Song, J. Y. Lee, E. Yoon and T. Yao, J. Appl. Phys., 2010, 107, 123519.

36 S.-Y. Chang, N.-H. Yang and Y.-C. Huang, J. Electrochem. Soc., 2009, 156, K200. 


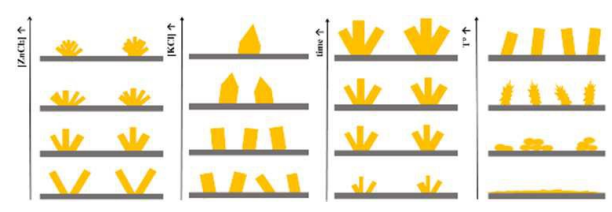

Effect of four parameters on the $\mathrm{ZnO}$ growth onto FTO 